\title{
Risk factors for perinatal death in two different levels of care: a case-control study
}

\author{
Paula Maria Silveira Soares Moura', Izildinha Maestá2 ${ }^{*}$, Lígia Maria Souza Suppo Rugolo³, \\ Luís Felipe Ramos Berbel Angulski ${ }^{4}$, Antônio Prates Caldeira ${ }^{5}$, José Carlos Peraçoli ${ }^{6}$ \\ and Marilza Vieira Cunha Rudge ${ }^{6}$
}

\begin{abstract}
Background: According to the World Health Organization, there are over 6.3 million perinatal deaths (PND) a year worldwide. Identifying the factors associated with PND is very helpful in building strategies to improve the care provided to mothers and their babies.

Objective: To investigate the maternal, gestational and neonatal factors associated with PND at two different levels of care.

Methods: Case-control study including 299 PND cases and 1161 infants that survived the early neonatal period (controls) between 2001-2006 in two hospitals at different care levels (secondary and tertiary) located in southeastern Brazil. Correlations between study variables and PND were evaluated by univariate analysis. PND-related variables were included in a multiple logistic regression model, and independent estimates of PND risk were obtained.

Results: Although five-minute Apgar score $<7$, low birthweight and maternal hemorrhage were associated with PND in the secondary care center, no independent risk factors were identified at this level of care. In the tertiary hospital, PND was positively associated with primiparity, male sex, prematurity, low 5-minute Apgar score, and pregnancy complicated by arterial hypertension or intrauterine infection.

Conclusions: Several risk factors positively associated with PND were indentified in the tertiary, but not in the secondary care level hospital. Since most of the risk factors herein identified are modifiable through effective antenatal and intrapartum care, greater attention should be given to preventive strategies.
\end{abstract}

Keywords: Perinatal death, Risk factors, Care levels, Maternity

\section{Introduction}

Perinatal death (PND) is an important indicator of maternal care and of maternal health and nutrition. It also reflects the quality of obstetric and pediatric care available [1,2]. It has been associated to maternal, gestational and neonatal factors such as maternal age, parity, maternal diseases, multiple gestation, birth route and gestational age [2-4], as well as low birthweight and fetal growth restriction $[2,4]$.

According to the World Health Organization (WHO) [5], there are over 6.3 million perinatal deaths a year worldwide. Of these, 2.64 million are stillbirths and 3.0

\footnotetext{
* Correspondence: imaesta@fmb.unesp.br

${ }^{2}$ Department of Gynecology and Obstetrics, Botucatu Medical School,

São Paulo State University-UNESP, Botucatu, Brazil

Full list of author information is available at the end of the article
}

million are cases of early neonatal death. Ninety-eight per cent of these deaths take place in developing countries [6].

In Brazil, the few studies available on perinatal mortality focus on local realities and report rates two- to three-fold higher than those found in developed countries [1,3,7]. In the state of São Paulo, END rate was 15.2/1000 live births in 2005 [8]. In the municipality of Botucatu, the only records available cover the period of 1991/1992, when PND was 14/1000 livebirths [9].

Identifying the factors associated with PND is very helpful in building strategies to improve the care provided to mothers and their babies. Therefore, the objective of this study was to investigate the maternal, gestational and neonatal factors associated with PND

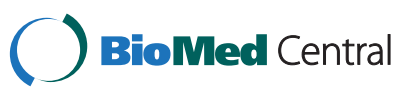


at different care levels (secondary and tertiary) in Botucatu/SP, Brazil.

\section{Methods}

In this case-control study, 299 PND cases and 1161 infants who survived the early neonatal period (controls) were assessed between January 1, 2001 and December 31, 2006 in two hospitals at different levels of care: Sorocabano Hospital (level II hospital), and Botucatu Medical School Hospital (level III-hospital), which are both located in Botucatu/SP, Brazil, and cover a population of approximately 1.2 million people. These regional maternal and perinatal services are essentially an institution-based hierarchical system with Level III hospital at the top. Care level was classified into two types based on the complexity of the treatments provided. Third level (higher complexity) hospital criteria included: complete maternity and neonatal care, intrapartum and neonatal intensive care, transport service, outreach education services, analysis and evaluation of new technologies. Second level (lower complexity) criteria included: 24-hour in-house anesthesia service, 24-hour clinical laboratory and radiology services, stabilization and transfer of complicated obstetric cases including preterm deliveries occurring before 34 weeks of gestation [10].

Cases were all stillbirths and early neonatal deaths documented during the study period in both participating hospitals. Infants who survived the early neonatal period were randomly selected to serve as controls. A 1:3 case to control ratio was used with week of birth being the matching criterion $(\alpha=0.05, \beta=0.20)$.

Data on maternal, gestational, and neonatal characteristics were obtained from hospital delivery and birth logs, medical records, necropsy reports, and death certificates. Maternal characteristics included age $(<20$ years, 20-34 years, and $\geq 35$ years), parity (primiparous or multiparous), and presence of hypertensive disorders, antepartum hemorrhage, hyperglycemia, intrauterine infection, urinary infection, and cardiovascular diseases. The same diagnostic criteria were followed in both participating hospitals (see box of definitions). Gestational characteristics consisted of gestation type (single or multiple), gestational age in weeks (determined by the mother's last menstrual period or early ultrasound) stratified into seven groups (22-26, 27-28, 29-30, 31-33, 34-36, 37-41, 42-43 weeks), and delivery route (vaginal or Cesarean). Neonatal characteristics comprised newborn sex, oneminute Apgar score ( $\leq 3,4-6$ and $\geq 7)$, five-minute Apgar score (0-6 and $\geq 7$ ), and birthweight in grams stratified in 6 groups (500-749 g, 750-999 g, 1000-1499 g, 1500-2499 g, 2500-3999 g, and $\geq 4000 \mathrm{~g})$.

The study was approved by the Research Ethics Committee of Botucatu Medical School, São Paulo State University-Unesp (\# 2234/2006).

\section{Definitions}

Perinatal period: between 22 completed weeks (154 days) of gestation and six completed days after birth.

Perinatal death (PND): number of stillbirths $(\geq 500 \mathrm{~g}$ or $\geq 22$ weeks of gestation) and deaths in the first week of life per 1,000 live births [5].

Hypertensive disorders: gestational hypertension, preeclampsia, superimposed preeclampsia, and chronic hypertension [11].

Antepartum hemorrhage $(\mathrm{APH})$ : vaginal bleeding from 20-24 weeks of gestation to term, as a result of placental abruption or placenta previa

Hyperglycemia: normal 100-g GTT + abnormal GP or abnormal 100-g GTT + abnormal GP) [12].

Intrauterine infection: histological report (if available) indicating chorioamnionitis, definite or probable neonatal sepsis, or two or more of: maternal fever, maternal tachycardia, fetal tachycardia, uterine tenderness and increasing maternal leukocytosis) Urinary infection: > 100,000 organisms.

Data analysis was performed using SPSS/Windows ${ }^{\oplus}$ version 12 software. The associations between perinatal death and primiparity, hypertensive disorders, uterine infection, gestational age, sex, and Apgar score were assessed by calculating the odds ratio (OR) and $95 \%$ confidence intervals $(95 \% \mathrm{CI})$ in a univariate analysis. Death-related variables were included in a multiple logistic regression model to obtain independent estimates of PND risk.

\section{Results}

During the study period, 312 cases of PND occurred in the participating hospitals. Thirteen of these cases were excluded due to data unavailability. Of the 299 PND cases enrolled, 277 took place at the tertiary hospital while 22 occurred in the secondary hospital. A total of 1161 babies survived the early perinatal period (controls). Of these, 1081 were enrolled in the tertiary hospital (total births during the study period $=7470$ ), and 80 in the secondary hospital (total births during the study period $=6699$ ).

Tables 1, 2 and 3 show univariate analysis results regarding maternal, gestational, and neonatal factors associated with perinatal death in both study hospitals.

Analysis of the associations between perinatal death and maternal characteristics revealed that increased death risk ( $\mathrm{p}<0.001, \mathrm{X}^{2}$ test) was associated with primiparity, hemorrhage, arterial hypertension, intrauterine infection and urinary infection in the tertiary level, whereas in the secondary level it was associated only with maternal hemorrhage ( $\mathrm{p}=0.009$, Fisher's exact test) (Table 1).

In relation to gestational characteristics, PND risk was three-fold increased by multiple gestations $(\mathrm{OR}=3.06$; 
Table 1 Associations of perinatal death (PND) with maternal characteristics at both the tertiary and secondary care level hospitals (2001-2006)

\begin{tabular}{|c|c|c|c|c|c|c|c|c|}
\hline \multirow[b]{2}{*}{$\begin{array}{l}\text { Maternal } \\
\text { characteristic }\end{array}$} & \multicolumn{4}{|c|}{ Level III Hospital } & \multicolumn{4}{|c|}{ Level II Hospital } \\
\hline & $\begin{array}{c}\text { PND } \\
(n=277)\end{array}$ & $\begin{array}{l}\text { Controls } \\
(n=1081)\end{array}$ & $\begin{array}{c}\text { OR } \\
(95 \% \mathrm{Cl})\end{array}$ & $\mathbf{p}$ & $\begin{array}{c}\text { PND } \\
(n=22)\end{array}$ & $\begin{array}{l}\text { Controls } \\
(n=80)\end{array}$ & $\begin{array}{c}\text { OR } \\
(95 \% \mathrm{Cl})\end{array}$ & $\mathbf{p}$ \\
\hline \multicolumn{9}{|c|}{ Maternal age (years) } \\
\hline $20-34$ years & $176(63.5 \%)$ & $682(63.1 \%)$ & 1.00 & & $14(63.6 \%)$ & $51(63.8 \%)$ & 1.00 & \\
\hline$<20$ years & $73(26.4 \%)$ & $285(26.4 \%)$ & $0.99(0.73-1.35)$ & $0.969^{(1)}$ & $5(22.7 \%)$ & $21(26.3 \%)$ & $0.87(0.28-2.71)$ & $0.967^{(1)}$ \\
\hline$\geq 35$ years & $28(10.1 \%)$ & $114(10.5 \%)$ & $0.96(0.62-1.50)$ & $0.863^{(1)}$ & $3(13.6 \%)$ & $8(10.0 \%)$ & $1.37(0.32-5.84)$ & $0.701^{(2)}$ \\
\hline \multicolumn{9}{|l|}{ Parity } \\
\hline Multíparous & $167(60.3 \%)$ & $811(75 \%)$ & 1.00 & & $15(68.2 \%)$ & $59(73.8 \%)$ & 1.00 & \\
\hline Primíparous & $110(39.7 \%)$ & $270(25 \%)$ & $1.97(1.49-2.61)$ & $<0.001^{(1)}$ & 7 (31.8\%) & $21(26.2 \%)$ & $1.31(0.47-3.65)$ & $0.604^{(1)}$ \\
\hline \multicolumn{9}{|l|}{ Hemorrhage } \\
\hline No & $250(90.2 \%)$ & 1060 (98.1\%) & 1.00 & & $19(86.4 \%)$ & $80(100.0 \%)$ & 1.00 & \\
\hline Yes & $27(9.8 \%)$ & $21(1.9 \%)$ & $5.75(3.17-10.42)$ & $<0.001^{(1)}$ & $3(13.6 \%)$ & $0(0.0 \%)$ & --- & $0.009^{(2)}$ \\
\hline \multicolumn{9}{|c|}{ Arterial hypertension } \\
\hline No & $209(75.5 \%)$ & $930(86.0 \%)$ & 1.00 & & $19(86.4 \%)$ & $78(97.5 \%)$ & 1.00 & \\
\hline Yes & $68(24.5 \%)$ & $151(14.0 \%)$ & $2.00(1.45-2.77)$ & $<0.001^{(1)}$ & $3(13.6 \%)$ & $2(2.5 \%)$ & $6.16(0.96-39.48)$ & $0.066^{(2)}$ \\
\hline \multicolumn{9}{|c|}{ Intrauterine infection } \\
\hline No & $230(83.0 \%)$ & 1047 (96.9\%) & 1.00 & & $21(95.5 \%)$ & $78(97.5 \%)$ & 1.00 & \\
\hline Yes & $47(17.0 \%)$ & $34(3.1 \%)$ & $6.49(4.07-10.36)$ & $<0.001^{(1)}$ & $1(4.5 \%)$ & $2(2.5 \%)$ & $1.86(0.16-21.49)$ & $0.521^{(2)}$ \\
\hline \multicolumn{9}{|l|}{ Diabetes } \\
\hline No & $262(94.6 \%)$ & $1025(94.8 \%)$ & 1.00 & & $22(100.0 \%)$ & $78(97.5 \%)$ & 1.00 & \\
\hline Yes & $15(5.4 \%)$ & $36(5.2 \%)$ & $1.05(0.58-1.88)$ & $0.876^{(1)}$ & $0(0.0 \%)$ & $2(2.5 \%)$ & --- & $1.000^{(2)}$ \\
\hline \multicolumn{9}{|l|}{ Cardiopathy } \\
\hline No & $269(97.1 \%)$ & 1059 (98.0\%) & 1.00 & & $22(100.0 \%)$ & $79(98.8 \%)$ & 1.00 & \\
\hline Yes & $8(2.9 \%)$ & $22(2.0 \%)$ & $1.43(0.63-3.25)$ & $0.389^{(1)}$ & $0(0.0 \%)$ & $1(1.2 \%)$ & --- & $1.000^{(2)}$ \\
\hline \multicolumn{9}{|c|}{ Urinary infection } \\
\hline No & $239(86.3 \%)$ & $1045(96.7 \%)$ & 1.00 & & $22(100.0 \%)$ & $79(98.8 \%)$ & 1.00 & \\
\hline Yes & $38(13.7 \%)$ & $36(3.3 \%)$ & $4.62(2.86-7.44)$ & $<0.001^{(1)}$ & $0(0.0 \%)$ & $1(1.2 \%)$ & --- & $1.000^{(2)}$ \\
\hline
\end{tabular}

${ }^{(1)}$ Chi-square test.

${ }^{(2)}$ Fisher's exact test.

CI 95\% $=2.00-4.68 ; \mathrm{p}<0.001)$, and was inversely proportional to gestational age $\left(\mathrm{p}<0.001 \chi^{2}\right.$ test or Fisher's exact test) in the tertiary hospital. In the level II hospital, no significant association between gestational age and PND was observed (Table 2).

Of the 277 perinatal deaths occurring at the tertiary hospital, 130 (46.9\%) occurred during the early neonatal period (from birth to 6 days of age). At this level of care, lower birthweight was associated with higher mortality ( $\mathrm{p}<0.001, \mathrm{x}^{2}$ test). Additionally, PND risk was increased two-fold in male infants $(\mathrm{OR}=1.95$; CI 95\% $=1.32-2.88$; $\mathrm{p}<0.001)$, and a 1-minute Apgar score $<7$ led to a threefold increase in the risk of PND (OR $=2.88$; CI 95\% $=1.61-$ 5.15; $\mathrm{p}<0.001$ ), while a 5-minute Apgar score $<7$ was associated with an increase of more than 140-fold in death risk $(\mathrm{OR}=141.87$; CI 95\% = 69.35 - 290.21; p < 0.001) (Table 3 ). In the secondary hospital, few PND cases occurred during the early neonatal period (6/22; $27 \%)$, and only 5-minute Apgar score $<7$ was associated with PND ( $\mathrm{p}<0.001$, Fisher's exact test) (Table 3 ).

Multivariate analysis showed that, at the level III hospital, primiparity, maternal hypertension, intrauterine infection, gestational age, male sex, and 5-minute Apgar score were significant risk factors for perinatal death (Table 4). In the level II hospital, no risk factors were significantly associated with PND.

\section{Discussion}

Our results show that no maternal risk factor reached significance for PND at the level II hospital. This is likely to be due to the effectiveness of the referral program that incorporates the two hospitals participating in this study, which are identified according to the complexity of the treatment they provide. Thus, while all low-risk pregnant 
Table 2 Associations of perinatal death (PND) with gestational characteristics at both the tertiary and secondary care level hospitals (2001-2006)

\begin{tabular}{|c|c|c|c|c|c|c|c|c|}
\hline \multirow[b]{2}{*}{ Gestational characteristics } & \multicolumn{4}{|c|}{ Hospital level III } & \multicolumn{4}{|c|}{ Hospital level II } \\
\hline & $\begin{array}{c}\text { PND } \\
(n=277)\end{array}$ & $\begin{array}{l}\text { Controls } \\
(n=1081)\end{array}$ & $\begin{array}{c}\text { OR } \\
(95 \% \mathrm{Cl})\end{array}$ & p & $\begin{array}{c}\text { PND } \\
(n=22)\end{array}$ & $\begin{array}{l}\text { Controls } \\
(n=80)\end{array}$ & $\begin{array}{c}\text { OR } \\
(95 \% \mathrm{Cl})\end{array}$ & $\mathrm{p}$ \\
\hline \multicolumn{9}{|l|}{ Gestation type } \\
\hline Single & $236(85.2 \%)$ & $1023(94.6 \%)$ & 1.00 & & $22(100.0 \%)$ & $78(97.5 \%)$ & 1.00 & \\
\hline Multiple & $41(14.8 \%)$ & $(5.4 \%)$ & $3.06(2.00-4.68)$ & $<0.001^{(1)}$ & $0(0.0 \%)$ & $(2.5 \%)$ & --- & $1.000^{(2)}$ \\
\hline \multicolumn{9}{|l|}{ Gestational age (weeks) } \\
\hline 37 - 41 (Term) & $41(14.8 \%)$ & $644(59.6 \%)$ & 1.00 & & $15(66.6 \%)$ & $68(85.0 \%)$ & 1.00 & \\
\hline 42 - 43 (Post-term) & $11(0.4 \%)$ & $65(0.6 \%)$ & $2.62(0.31-21.80)$ & $0.351^{(2)}$ & $1(4.8 \%)$ & $0(0.0 \%)$ & --- & $0.180^{(2)}$ \\
\hline 34 - 36 (Late pre-term) & $40(14.3 \%)$ & $147(13.6 \%)$ & $3.92(2.49-6.19)$ & $<0.001^{(1)}$ & $0(0.0 \%)$ & $8(10.0 \%)$ & --- & $0.348^{(2)}$ \\
\hline 31 - 33 (Pre-term) & $31(11.2 \%)$ & $69(6.4 \%)$ & $7.79(4.61-13.16)$ & $<0.001^{(1)}$ & $1(4.8 \%)$ & $1(1.2 \%)$ & $4.86(0.29-82.38)$ & $0.327^{(2)}$ \\
\hline $29-30$ (Extremely pre-term) & $34(12.3 \%)$ & $17(1.6 \%)$ & 36.68 (18.93-71.09) & $<0.001^{(1)}$ & $0(0.0 \%)$ & $0(0.0 \%)$ & --- & $1.000^{(2)}$ \\
\hline 27 - 28 (Extremely pre-term) & $33(11.9 \%)$ & $19(1.8 \%)$ & $31.86(16.70-60.78)$ & $<0.001^{(1)}$ & $0(0.0 \%)$ & $2(2.5 \%)$ & --- & $1.000^{(2)}$ \\
\hline 24 - 26 (Periviable) & $51(18.5 \%)$ & $86(0.8 \%)$ & 110.05 (50.83-238.28) & $<0.001^{(1)}$ & $2(9.5 \%)$ & $1(1.3 \%)$ & $9.71(0.82-114.67)$ & $0.089^{(2)}$ \\
\hline 22 - 23 (Not viable) & $36(13.0 \%)$ & $32(0.3 \%)$ & $220.10(65.04-744.79)$ & $<0.001^{(2)}$ & $3(14.3 \%)$ & $0(0.0 \%)$ & --- & $0.006^{(2)}$ \\
\hline \multicolumn{9}{|l|}{ Type of delivery } \\
\hline Vaginal & $171(61.7 \%)$ & $(54.9 \%)$ & 1.00 & & $17(77.3 \%)$ & $42(52.5 \%)$ & 1.00 & \\
\hline Cesarean & $106(38.3 \%)$ & (45.1\%) & $0.75(0.57-0.98)$ & $0.041^{(1)}$ & 5 (22.7\%) & $38(47.5 \%)$ & $0.32(0.10-0.96)$ & $0.037^{(1)}$ \\
\hline
\end{tabular}

${ }^{(1)}$ Chi-square test.

${ }^{(2)}$ Fisher's exact test.

Table 3 Associations of perinatal death (PND) with neonatal characteristics at both the tertiary and secondary care level hospitals (2001-2006)

\begin{tabular}{|c|c|c|c|c|c|c|c|c|}
\hline \multirow[b]{2}{*}{$\begin{array}{l}\text { Neonatal } \\
\text { characteristics }\end{array}$} & \multicolumn{4}{|c|}{ Hospital level III } & \multicolumn{4}{|c|}{ Hospital level II } \\
\hline & $\begin{array}{l}\text { PND }^{(*)} \\
(n=130)\end{array}$ & $\begin{array}{l}\text { Controls } \\
(n=1081)\end{array}$ & OR $(95 \% \mathrm{Cl})$ & $\mathrm{p}$ & $\begin{array}{l}\text { PND }{ }^{(*)} \\
(n=6)\end{array}$ & $\begin{array}{l}\text { Controls } \\
(n=80)\end{array}$ & OR $(95 \% \mathrm{Cl})$ & $\mathbf{p}$ \\
\hline \multicolumn{9}{|l|}{ Gender } \\
\hline Female & $40(30.8 \%)$ & $491(45.4 \%)$ & 1.00 & & $4(66.7 \%)$ & $34(42.5 \%)$ & 1.00 & \\
\hline Male & $90(69.2 \%)$ & $590(54.6 \%)$ & $1.95(1.32-2.88)$ & $p<0.001^{(1)}$ & $2(33.3 \%)$ & $46(57.5 \%)$ & $0.37(0.06-2.14)$ & $p=0.398^{(2)}$ \\
\hline \multicolumn{9}{|c|}{ 1-minute Apgar score } \\
\hline$\geq 7$ & $84(64.3 \%)$ & $906(83.8 \%)$ & 1.00 & & $2(33.3 \%)$ & $68(85.0 \%)$ & 1.00 & \\
\hline $4-6$ & $29(22.2 \%)$ & $109(10.1 \%)$ & $2.86(1.78-4.59)$ & $p<0.001^{(1)}$ & $2(33.3 \%)$ & $9(11.2 \%)$ & $7.56(0.43-131.63)$ & $p=0.238^{(2)}$ \\
\hline $0-3$ & $18(13.5 \%)$ & $66(6.1 \%)$ & $2.88(1.61-5.15)$ & $p<0.001^{(1)}$ & $2(33.3 \%)$ & $3(3.8 \%)$ & $22.67(1.12-456.81)$ & $p=0.107^{(2)}$ \\
\hline \multicolumn{9}{|c|}{ 5-minute Apgar score } \\
\hline$\geq 7$ & $56(42.9 \%)$ & 1071 (99.1\%) & 1.00 & & $2(33.3 \%)$ & $80(100.0 \%)$ & 1.00 & \\
\hline $0-6$ & $74(57.1 \%)$ & $10(0.9 \%)$ & $141.87(69.35-290.21)$ & $p<0.001^{(1)}$ & $4(66.7 \%)$ & $0(0.0 \%)$ & $---(-)$ & $p<0.001^{(2)}$ \\
\hline \multicolumn{9}{|l|}{ Birthweight (g) } \\
\hline $2500-3999$ & $23(17.7 \%)$ & $780(72.2 \%)$ & 1.00 & & $4(66.6 \%)$ & $70(87.5 \%)$ & 1.00 & \\
\hline$\geq 4000$ & $0(0.0 \%)$ & $45(4.2 \%)$ & --- --- & $p=0.628^{(2)}$ & $0(0.0 \%)$ & $1(1.3 \%)$ & --- --- & $p=1.000^{(2)}$ \\
\hline $1500-2499$ & $29(22.3 \%)$ & $197(18.2 \%)$ & $4.97(2.81-8.77)$ & $\mathrm{p}<0.001^{(1)}$ & $1(16.7 \%)$ & $6(7.4 \%)$ & $2.92(0.28-30.42)$ & $p=0.371^{(2)}$ \\
\hline $1000-1499$ & $13(10.0 \%)$ & $31(2.9 \%)$ & $14.22(6.59-30.69)$ & $p<0.001^{(1)}$ & $0(0.0 \%)$ & $2(2.5 \%)$ & $---(-)$ & $p=1.000^{(2)}$ \\
\hline $750-999$ & $24(18.5 \%)$ & $14(1.3 \%)$ & $54.14(26.68-126.66)$ & $p<0.001^{(1)}$ & $0(0.0 \%)$ & $0(0.0 \%)$ & $---(-)$ & $p=1.000^{(2)}$ \\
\hline $500-749$ & 41 (31.5\%) & $13(1.2 \%)$ & $106.96(50.57-226.22)$ & $p<0.001^{(1)}$ & $1(16.7 \%)$ & $1(1.3 \%)$ & $17.50(0.92-334.13)$ & $p=0.128^{(2)}$ \\
\hline
\end{tabular}

${ }^{(1)}$ Chi-square test; ${ }^{(2)}$ Fisher's exact test;

$\left.{ }^{*}\right)$ Deaths occurring within the first week of life (0-6 days). 
Table 4 Multivariate analysis of the associations between independent variables and perinatal death at the tertiary care level hospital, 2001 - 2006

\begin{tabular}{lcccc}
\hline Characteristic & $\boldsymbol{\beta}$ & $\mathbf{p}$-value & OR & $\mathbf{9 5 \%} \mathbf{C l}$ \\
\hline Interceptus & 13.10 & 0.000 & 488618.38 & \\
Primiparity & 1.17 & 0.001 & 3.23 & $(1.62-6.43)$ \\
Arterial hypertension & 0.98 & 0.010 & 2.65 & $(1.27-5.55)$ \\
Intrauterine infection & 2.07 & 0.000 & 7.89 & $(2.66-23.39)$ \\
Gestational age (weeks) & -0.18 & 0.000 & 0.83 & $(0.78-0.89)$ \\
Male sex & 0.84 & 0.024 & 2.31 & $(1.12-4.76)$ \\
5-minute Apgar score & -1.24 & 0.000 & 0.29 & $(0.23-0.37)$ \\
\hline
\end{tabular}

Deviance $=264.95 ; \mathrm{X}^{2}=539.05 ; \mathrm{df}$ model $=6 ; \mathrm{p}<0.001$

$\mathrm{OR}=$ odds ratio.

women were planned to deliver at the level II hospital, all high-risk pregnancies, including preterm deliveries $(<34$ weeks of gestation), were referred to the level III hospital, unless they occurred urgently at the level II hospital before they could be referred [10].

In the participating level III hospital, primiparity, pregnancy complicated by arterial hypertension or intrauterine infection, prematurity, male sex, and low 5-minute Apgar score were found to be positively associated with perinatal death.

Other studies $[13,14]$ have also described primiparity as an independent risk factor for PND. This might be due to the poor maternal adaptation to pregnancy caused by inadequate uterine vascular response to pregnancy hemodynamic demand. These abnormalities result in placental ischemia that leads to release of circulating angiogenic factors that cause preeclampsia. An ischemic intrauterine environment can also lead to intrauterine growth restriction and fetal distress [15].

In the secondary hospital, as maternal disease is a reason for referral to a tertiary center, the frequency of maternal diseases was low. In the tertiary hospital, however, there was a significant association between maternal diseases and perinatal mortality. The fact that arterial hypertension and intrauterine infection were major causes of PND in this care level underscores the impact of these conditions on the conceptus.

Studies conducted in Latin America [4,16], as well as in developed countries $[17,18]$, have shown hypertensive disorders as the leading cause of PND. In pregnancies complicated by arterial hypertension, the impairment of uteroplacentary circulation may lead to intrauterine hypoxia or even stillbirth [19]. In addition, pregnancyinduced hypertension frequently causes prematurity, which also increases perinatal mortality.

Intrauterine infection increases the risk of neonatal death among both term and preterm infants [20,21]. Such complication may occur in the presence of prematurely ruptured ovular membranes with the ascent of cervicovaginal bacteria into the uterus $[20,21]$.

Twin pregnancy was associated with PND in univariate analysis, but it was not significant in the multivariate model. Multiple gestation poses high risks to both the fetuses and the mother [22], and is often associated with other risk factors such as low gestational age and low birthweight. In these cases, maternal and perinatal care should be provided at a tertiary care center $[22,23]$. It is worth of note that a multivariate logistic model was not attempted on the 22 PND cases in the level II hospital because of the small sample size.

Gestational age was an important risk factor for PND in the tertiary hospital. Indeed, a 17\% decrease in PND risk was observed at each additional week of gestation. In the secondary hospital, preterm birth rate was low probably because preterm labour cases were referred to the tertiary hospital that has an Intensive Neonatal Care Unit.

The fact that prematurity rates are increasing worldwide, including Brazil $[2,4,24]$, represents a major challenge to obstetricians and neonatologists seeking the reduction of perinatal mortality [24]. In developed countries, the threshold of viability at which the infant could have a $50 \%$ chance of survival if born prematurely is set at about 25 weeks of gestation $[25,26]$. In the participating tertiary hospital, the chance of death considerably dropped from 27 weeks of gestation onward, indicating a one-week reduction in fetal limit of viability as compared with local data from the past decade [27].

Although neonatal morbidity and mortality are primarily influenced by gestational age, birthweight (especially when $<750$ g) can change infant outcome [26]. Almost one third of the babies that died in the participating tertiary hospital weighed less than 750 g. However, birthweight was not an independent risk factor for perinatal death, confirming that gestational age has a greater influence than birthweight on neonatal outcome.

Infant mortality rates are known to be higher among males than females, though the exact cause remains unclear $[28,29]$. In this study, male sex was associated with a two-fold increase in perinatal death chance in the tertiary hospital.

Low 5-minute Apgar score is one of the markers of perinatal asphyxia. In line with other reports [3,16,30], this study showed that 5 -minute Apgar score $<7$ was a risk factor for PND. In a recent study of 19 Brazilian maternities and 15,169 liveborns, Pileggi et al. (2010) [31] demonstrated a significantly higher rate of early neonatal mortality among infants with 5-minute Apgar $<7$ compared with infants with 5-minute Apgar $\geq 7$ (25\% vs. 0.3\%, respectively). These data point to an important focus for intervention in order to improve perinatal outcomes: 
access to appropriate obstetric and neonatal care, particularly during labor and birth [3].

This study was limited by the small sample size of the level II hospital, and by its retrospective design, which did not allow considering all possible risk factors for perinatal mortality (e.g. congenital malformations, maternal smoking, syphilis, previous C-section, history of stillbirth, etc.) due to data unavailability. In spite of these limitations, our results show the importance of two-level referral systems for maternal and neonatal care based on the transport of high risk patients to the level of care offering the best chance for improved outcomes [10]. Nonetheless, as most of the risk factors herein identified may be modifiable through effective antenatal and intrapartum care, the adoption of preventive strategies should not be overlooked.

\section{Competing interests}

The authors declare that they have no competing interests.

\section{Authors' contributions}

PMSSM and IM had the original idea for the study. LMSSR was responsible for the plan of analysis. PMSSM and LFRBA were responsible for data collection. All authors saw the output of analysis and tables and commented on their significance. PMSSM and IM wrote the first version of the manuscript, which was then reviewed, and corrected by APC, JCP and MVCR. All authors read the final version of the manuscript and agreed with its content before submission.

\section{Acknowledgements}

The authors are thankful to Hélio Rubens Nunes for his help with statistical analysis, and to Mariza Branco da Silva for her assistance with the writing of the manuscript in English.

\section{Author details}

${ }^{1}$ Postgraduation Program in Gynecology, Obstetrics and Mastology, Botucatu Medical School, São Paulo State University-UNESP, Botucatu, Brazil. ${ }^{2}$ Department of Gynecology and Obstetrics, Botucatu Medical School, São Paulo State University-UNESP, Botucatu, Brazil. ${ }^{3}$ Departament of Pediatrics, Botucatu Medical School, São Paulo State University-UNESP,

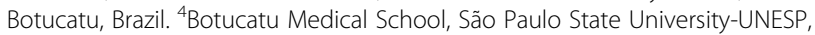
Scientific Initiation PIBIC/CNPq - Grant \#0113024/2008-8, Botucatu, Brazil. ${ }^{5}$ Departament of Women's and Children's Health, State University of Montes Claros-Unimontes (MG), Montes Claros, Brazil. ${ }^{6}$ Department of Gynecology and Obstetrics, Botucatu Medical School, São Paulo State University-UNESP, Botucatu, Brazil.

Received: 27 February 2013 Accepted: 10 January 2014

Published: 30 January 2014

\section{References}

1. Lansky S, França E, Leal MC: Mortes perinatais evitáveis em Belo Horizonte, Minas Gerais, 1999. Cad Saude Publica 2002, 18:1389-1400.

2. Aquino TA, Guimarães MJB, Sarinho SW, Ferreira LOC: Fatores de risco para a mortalidade perinatal no Recife, Pernambuco, Brasil, 2003. Cad Saude Publica 2007, 23:2853-2861.

3. Lansky S, França E, César CC, Monteiro Neto LC, Leal MC: Mortes perinatais e avaliação da assistência ao parto em maternidades do Sistema Único de Saúde em Belo Horizonte, Minas Gerais, Brasil, 1999. Cad Saude Publica 2006, 22:117-130.

4. Fonseca SC, Coutinho ESF, Freire ES: Características biológicas e evitabilidade de óbitos perinatais em uma localidade na cidade do Rio de Janeiro, 1999 a 2003. Rev Bras Saude Mater Infant 2008, 8:171-178.

5. World Health Organization: Neonatal and perinatal mortality: country, regional and global estimates. Geneva: World Health Organization; 2006.
6. Cousens S, Blencowe $H$, Stanton C, Chou D, Ahmed S, Steinhardt L, Creanga AA, Tunçalp O, Balsara ZP, Gupta S, Say L, Lawn JE: National, regional, and worldwide estimates of stillbirth rates in 2009 with trends since 1995: a systematic analysis. Lancet 2011, 377(9774):1319-1330.

7. Victora CG, Barros FC: Infant mortality due to perinatal causes in Brazil: trends, regional patterns and possible interventions. Sao Paulo Med J 2001, 119:33-42

8. Ministério da Saúde: IDB - indicadores e dados básicos - indicadores de mortalidade - mortalidade perinatal. 2007. http://tabenet.datasus.gov.br/cgi/ idb2007/matriz.htm.

9. Macharelli CA: Estudo da mortalidade perinatal em Botucatu, 1990/1991: Estudo de seus determinantes. In Dissertação. Ribeirão Preto: Universidade de São Paulo, Faculdade de Medicina; 1995.

10. Rudge MV, Maestá I, Moura PM, Rudge CV, Morceli G, Costa RA, Abbade J, Peraçoli JC, Witkin SS, Calderon IM, Collaborative group: The safe motherhood referral system to reduce cesarean sections and perinatal mortality - a cross-sectional study [1995-2006]. Reprod Health 2011, 8:34.

11. National High Blood Pressure Education Program Working Group : Report on High Blood Pressure in Pregnancy. Bethesda, MD: National Institutes of Health, National Heart, Lung and Blood Institute NIH publication No. 00-3029; 2000:1-38. http://www.nhlbi.nih.gov/health/prof/heart/hbp/ hbp_preg.pdf.

12. Rudge MV, Calderon IM, Ramos MD, Abbade JF, Rugolo LM: Perinatal outcome of pregnancies complicated by diabetes and by maternal daily hyperglycemia not related to diabetes: a retrospective 10-year analysis. Gynecol Obstet Invest 2000, 50:108-112.

13. Ego A, Subtil D, Grange G, Thiebaugeorges O, Senat MV, Wayssiere C, Zeitlin $\mathrm{J}$ : Should parity be included in customised fetal weight standards for identifying small-for-gestational-age babies? results from a French multicentre study. BJOG 2008, 115(10):1256-1264.

14. Zhang X, Mumford SL, Cnattingius S, Schisterman EF, Kramer MS: Reduced birthweight in short or primiparous mothers: physiological or pathological? BJOG 2010, 117(10):1248-1254.

15. Mackenzie RM, Sandrim VC, Carty DM, McClure JD, Freeman DJ, Dominiczak AF, McBride MW, Delles C: Endothelial FOS expression and pre-eclampsia. BJOG 2012, 119(13):1564-1571.

16. Araujo BF, Tanaka ACA, Madi JM, Zatti H: Estudo da mortalidade de recém-nascidos internados na UTI neonatal do hospital Geral de Caxias do Sul, Rio Grande do Sul. Rev Bras Saude Mater Infant 2005, 5:463-469.

17. Mackenzie Vigil-De Gracia P, Lasso M, Montufar-Rueda C: Perinatal outcome in women with severe chronic hypertension during the second half of pregnancy. Int J Gynaecol Obstet 2004, 85(2):139-144.

18. Zetterström K, Lindeberg SN, Haglund B, Hanson U: The association of maternal chronic hypertension with perinatal death in male and female offspring: a record linkage study of 866,188 women. BJOG 2008, 115(11):1436-1442

19. Freeman RK: Antepartum testing in patients with hypertensive disorders in pregnancy. Semin Perinatol 2008, 32(4):271-273.

20. Petrova A, Demissie K, Rhoads GG, Smulian JC, Marcella S, Ananth CV: Association of maternal fever during labor with neonatal and infant morbidity and mortality. Obstet Gynecol 2001, 98(1):20-27.

21. Bullard I, Vermillion S, Soper D: Clinical intraamniotic infection and the outcome for very low birth weight neonates. Am J Obstet Gynecol 2002, 187:S73

22. ACOG Committee Opinion: Number 369: june 2007: multifetal pregnancy reduction. Obstet Gynecol 2007, 109(6):1511-1515.

23. da Saúde M: Gestação de alto risco. 3a edição. Brasília: Ministério da Saúde: 2000:13-17. Manual Técnico.

24. Silveira MF, Santos IS, Barros AJ, Matijasevich A, Barros FC, Victora CG Increase in preterm births in Brazil: review of population-based studies. Rev Saude Publica 2008, 42(5):957-964.

25. Lemons JA, Bauer CR, Oh W, Korones SB, Papile LA, Stoll BJ, Verter J, Temprosa M, Wright LL, Ehrenkranz RA, Fanaroff AA, Stark A, Carlo W, Tyson JE, Donovan EF, Shankaran S, Stevenson DK: Very low birth weight outcomes of the national institute of child health and human development neonatal research network, January 1995 through December 1996. Pediatrics 2001, 107(1):E1.

26. Fanaroff AA, Stoll BJ, Wright LL, Carlo WA, Ehrenkranz RA, Stark AR, Bauer CR, Donovan EF, Korones SB, Laptook AR, Lemons JA, Oh W, Papile LA, 
Shankaran S, Stevenson DK, Tyson JE, Poole WK, NICHD Neonatal Research Network: Trends in neonatal morbidity and mortality for very low birthweight infants. Am J Obstet Gynecol 2007, 196(2):147. e1-8.

27. Prigenzi MLH, Trindade CEP, Rugolo LMSS, Silveira LVA: Fatores de risco associados à mortalidade de recém-nascidos de muito baixo peso na cidade de Botucatu, São Paulo, no período 1995-2000. Rev Bras Saude Mater Infant 2008, 8(1):93-101.

28. Naeye RL, Burt LS, Wright DL, Blanc WA, Tatter D: Neonatal mortality, the male disadvantage. Pediatrics 1971, 48(6):902-906.

29. Ingemarsson I: Gender aspects of preterm birth. BJOG 2003, 110(20):34-38.

30. Almeida MF, Guinsburg R, Martinez FE, Procianoy RS, Leone CR, Marba ST, Rugolo LM, Luz JH, Lopes JM: Perinatal factors associated with early deaths of preterm infants born in Brazilian network on neonatal research centers. J Pediatr (Rio J) 2008, 84:300-307.

31. Pileggi C, Souza JP, Cecatti JG, Faundes A: Neonatal near miss approach in the 2005 WHO global survey Brazil. J Pediatr (Rio J) 2010, 96:21-26.

\section{doi:10.1186/1742-4755-11-11}

Cite this article as: Moura et al.: Risk factors for perinatal death in two different levels of care: a case-control study. Reproductive Health 2014 11:11.

\section{Submit your next manuscript to BioMed Central and take full advantage of:}

- Convenient online submission

- Thorough peer review

- No space constraints or color figure charges

- Immediate publication on acceptance

- Inclusion in PubMed, CAS, Scopus and Google Scholar

- Research which is freely available for redistribution 